This item was submitted to Loughborough's Research Repository by the author.

Items in Figshare are protected by copyright, with all rights reserved, unless otherwise indicated.

\title{
Macroinvertebrate diversity in urban and rural ponds: implications for freshwater biodiversity conservation
}

PLEASE CITE THE PUBLISHED VERSION

http://dx.doi.org/10.1016/j.biocon.2016.06.027

PUBLISHER

(C) Elsevier

VERSION

AM (Accepted Manuscript)

\section{PUBLISHER STATEMENT}

This work is made available according to the conditions of the Creative Commons Attribution-NonCommercialNoDerivatives 4.0 International (CC BY-NC-ND 4.0) licence. Full details of this licence are available at: https://creativecommons.org/licenses/by-nc-nd/4.0/

\section{LICENCE}

CC BY-NC-ND 4.0

\section{REPOSITORY RECORD}

Hill, Matthew J., David Ryves, James C. White, and Paul Wood. 2019. "Macroinvertebrate Diversity in Urban and Rural Ponds: Implications for Freshwater Biodiversity Conservation". figshare. https://hdl.handle.net/2134/22175. 
1 Macroinvertebrate diversity in urban and rural ponds: implications for freshwater biodiversity

2 conservation

3 M. J. Hill ${ }^{1}$, D. B. Ryves, J. C. White and P. J. Wood $^{2}$

$4 \quad{ }^{1}$ Institute of Science and the Environment, University of Worcester, Henwick Grove, Worcester $5 \quad$ WR2 6AJ, UK.

$6 \quad{ }^{2}$ Centre for Hydrological and Ecosystem Science, Department of Geography, Loughborough

7 University, Loughborough, Leicestershire, LE11 3TU, UK

8

9 Author for correspondence

10 Matthew Hill

11 Institute of Science and the Environment

12 University of Worcester

13 Worcester

14 Worcestershire

15 WR2 6AJ

16 UK.

17

18

Tel: 0044 (0)1905 542441

19 Email: matthew.hill@worc.ac.uk

20

21

22

23

24

25

26

27

28 


\section{Abstract}

30 Ponds are among the most biodiverse freshwater ecosystems, yet face significant threats from removal,

31 habitat degradation and a lack of legislative protection globally. Information regarding the habitat 32 quality and biodiversity of ponds across a range of land uses is vital for the long term conservation 33 and management of ecological resources. In this study we examine the biodiversity and conservation 34 value of macroinvertebrates from 91 lowland ponds across 3 land use types (35 floodplain meadow, 3515 arable and 41 urban ponds). A total of 224 macroinvertebrate taxa were recorded across all ponds, 36 with urban ponds and floodplain ponds supporting a greater richness than arable ponds at the 37 landscape scale. However, at the alpha scale, urban ponds supported lower faunal diversity (mean: 22 taxa) than floodplain (mean: 32 taxa) or arable ponds (mean: 30 taxa). Floodplain ponds were found to support taxonomically distinct communities compared to arable and urban ponds. A total of 13 macroinvertebrate taxa with a national conservation designation were recorded across the study area and 12 ponds (11 floodplain and 1 arable pond) supported assemblages of high or very high conservation value. Pond conservation currently relies on the designation of individual ponds based on very high biodiversity or the presence of taxa with specific conservation designations. However, this site specific approach fails to acknowledge the contribution of ponds to freshwater biodiversity at the landscape scale. Ponds are highly appropriate sites outside of protected areas (urban/arable), with which the general public are already familiar, for local and landscape scale conservation of freshwater habitats.

Key words: Conservation value, landscape scale, reconciliation ecology, small lentic waterbodies, taxonomic richness

51 


\section{1. Introduction}

58 Freshwaters support some of the most biologically rich and diverse habitats yet include some of the most threatened ecosystems at a global scale (Dudgeon et al., 2006; Gioria et al., 2010). The threats to freshwater biodiversity have been recognised at a policy level, including the over exploitation of their physical (e.g., water) and biological resources (e.g., fisheries), pollution, modification of the hydrological regime, degradation in habitat quality and colonisation by non-native species. As a result, freshwater ecosystems have been a key conservation priority over the last decade following the adoption of resolution 58/217 by the United Nations determining 2005-2015 as the international decade for action on 'water for life' (Dudgeon et al., 2006).

66

67 Over the last two decades, research centred on the conservation of pond flora and fauna has increased significantly, with the number of primary research papers published within academic journals addressing pond biodiversity tripling in the last decade (Cereghino et al., 2014). Previous research has demonstrated that ponds (standing waterbody between $25 \mathrm{~m}^{2}$ and 2 ha in size; Williams et al., 2010) have the capacity to support a greater biodiversity of aquatic macroinvertebrates and macrophytes, as well as higher proportions of rare and endemic species than other freshwater habitats (Williams et al., 2003; Davies et al., 2008). This contribution to biodiversity may become particularly important in anthropogenically-dominated urban landscapes and intensive agricultural areas, where ponds may represent biodiversity hotspots and islands of aquatic habitat in otherwise ecologically poor environments (Sayer et al., 2012; Cereghino et al., 2014). Moreover, ponds provide a range of ecosystem services including; 1) environmentally sustainable solutions to water management - water storage (flood alleviation), nutrient and sediment retention, and; 2) local scale carbon storage/sequestration and mitigation for urban heat island effects (Downing et al., 2008; Coutts et al., 2012; Cereghino et al., 2014; Hassall, 2014).

81

82 Despite the wider importance of ponds to society and biological communities, freshwater 83 conservation efforts globally have been primarily focussed on lotic and larger lentic waterbodies,

84 whilst small freshwater bodies have been largely ignored (Williams et al., 2003; Oertli et al., 2009). 
International legislation in relation to freshwater resources and ecosystems falls into two broad categories; 1) pollution and water resources - legislation focussed on improving the quality of

87 freshwater and; 2) nature conservation - legislation orientated towards the protection of habitats that are under significant threat and species with specific designations (Hassall et al., 2016). At a European scale these two categories form the basis for the EU Water Framework Directive (WFD; pollution and water resources) and the EU Habitats Directive (nature conservation) which have been incorporated into national legislation across the $28 \mathrm{EU}$ member states (Hassall et al., 2016). However, the WFD only affords protection to larger lentic systems (lakes >50ha), despite its key objective to improve the quality of all freshwater habitats (EC, 2000; Sayer, 2014). More recently national and international nature conservation agencies have highlighted the value of ponds more readily than those responsible for water resources and as a result, nature conservation legislation has afforded greater (but still significantly limited) protection to pond habitats and their biodiversity (Hassall et al., 2016). A limited number of pond types (e.g., Mediterranean temporary ponds) and species associated with them (e.g., the Great Crested Newt, Triturus cristatus) are recognised under the EU Habitats Directive (Oertli et al., 2005). However, in the absence of statutory routine (regular) monitoring of ponds across most of Europe, it is likely many ponds which meet the requirements to be afforded protection have been overlooked (Biggs et al., 2005). As a result of the lack of legislative protection, many ponds have been lost to infilling/drainage due to agricultural intensification or urban development, which has led to increasingly fragmented and isolated pond networks (Hull, 1997;

104 Wood et al., 2003; Zacharias et al., 2007; Davies et al., 2009). In addition, many ponds suffer from 105 poor habitat and water quality due to nutrient enrichment (chemical and organic) and the introduction of non-native species (Biggs et al., 2007; Williams et al., 2010).

While designated areas remain important to protect species and habitats, there is a need to consider biodiversity conservation outside of protected areas as the small land coverage of nature reserves is

110 likely to be insufficient to protect the majority of biodiversity (Le Viol et al., 2009). Ponds are a 111 common landscape features globally (Downing et al., 2006), and may provide suitable habitats and 112 important refuges for aquatic and riparian flora and fauna in anthropogenically-dominated landscapes 
113 (Chester and Robson, 2013; Hassall and Anderson, 2015) yet comparatively little is known about their

114 wider value.

116 Given the potentially high ecological value of ponds, information regarding their biological quality is

117 vital to the long term conservation and management of freshwater biodiversity (Gioria et al., 2010).

118 Pond biodiversity research at larger scales has typically focussed on invertebrate diversity within a

119 particular landscape setting (Céréghino et al., 2008; Gledhill et al., 2008; Usio et al., 2013). This is the

120 first study to our knowledge which has considered the regional macroinvertebrate biodiversity of

121 ponds across a range of lowland land use types. The current investigation of lowland ponds within a

122 mixed urban and agricultural landscape setting specifically sought to: (1) quantify the

123 macroinvertebrate diversity associated with floodplain, agricultural arable and urban ponds; (2)

124 characterise the heterogeneity of faunal communities between and among floodplain, agricultural

125 arable and urban ponds and; (3) examine the importance of ponds to landscape-scale biodiversity 126 conservation.

\section{2. Materials and Methods}

129 2.1 Site Selection

130 A total of 91 ponds were examined (67 perennial, 24 ephemeral), close to the town of Loughborough

131 (Leicestershire, UK; Fig. 1). The study area has a temperate climate with an average annual minimum

132 temperature of $6.1^{\circ} \mathrm{C}$, an average annual maximum temperature of $13.9{ }^{\circ} \mathrm{C}$ and mean annual

133 precipitation of $620.2 \mathrm{~mm}$ (1981-2010, data provided by the Met Office; Met Office, 2015). An

134 exhaustive survey of pond habitats was undertaken using maps and aerial images using Google Earth

135 software (Google Earth, 2015) to identify ponds in the study area. The ponds were located in three

136 common land-use types typical of lowland landscapes in Europe; (i) floodplain ponds (35) located on

137 floodplain meadows which are protected for nature conservation (Nature Reserves) and were naturally

138 inundated by water from the River Soar during the winter and early spring; (ii) arable ponds (15) -

139 located on intensively cultivated land - predominantly rapeseed or wheat crops; and (iii) urban ponds

140 (41) - located within residential gardens, public spaces (parks), school grounds (used as educational 
141 tools) and high density commercial developments (urban drainage ponds; industrial, roadside and

142 town centre locations; Hill et al., 2015). It is widely acknowledged that there are large numbers of

143 urban ponds (Hassall, 2014) and floodplain ponds across the UK, whilst agricultural pond numbers

144 have been in consistent decline for many decades (Wood et al., 2003). In addition, difficulties

145 surrounding access to agricultural land when in crop resulted in the number of arable ponds surveyed

146 being lower than urban and floodplain ponds.

\section{$148 \quad 2.2$ Macroinvertebrate sampling}

149 Each pond was sampled for aquatic macroinvertebrates on three occasions corresponding to spring

150 (March), summer (June) and autumn (September) in 2012. Full details and rationale of field and

151 laboratory sampling procedures are presented in Hill et al. (2015) and summarized here. The length of

152 time allocated to sample aquatic macroinvertebrates in each pond was proportional to its surface area

153 (Hinden et al., 2005) up to a maximum of three minutes (Biggs et al., 1998). A total of three minutes

154 sampling time was assigned to ponds greater than $50 \mathrm{~m}^{2}$; for smaller ponds 30 seconds of sampling

155 for every $10 \mathrm{~m}^{2}$ surface area was employed. Sampling time allocated to each pond was divided

156 equally between the mesohabitats present (e.g., submerged macrophytes, emergent macrophytes,

157 floating macrophytes and open water) although, if a single mesohabitat dominated the pond, sampling

158 time was divided further to reflect this (Biggs et al., 1998). An inspection of any larger substrates (e.g.,

159 rocks) that could not be sampled with a pond net was undertaken for up to 60 seconds to ensure that

160 all available habitats were sampled. Aquatic macroinvertebrate samples were processed in the

161 laboratory and preserved in 70\% industrial methylated spirits. Macroinvertebrate taxa were identified

162 to species level wherever possible, although Diptera larvae, Planariidae and Physidae were identified

163 to family level and Collembola, Hydrachnidiae and Oligochaeta were identified as such.

\subsection{Environmental data collection}

166 At each sample site a range of environmental characteristics were recorded including; surface area

$167\left(\mathrm{~m}^{2}\right)$, mean water depth $(\mathrm{cm})$, dry phase (duration during the 12-month study period that the pond was

168 dry), the percentage of the pond margin that was shaded, conductivity (microS cm${ }^{-1}$ : recorded using a 
169 Hanna conductivity meter: HI198311), pH (recorded using a Hanna pH meter: HI98127), water

170 temperature, (recorded using a Hanna $\mathrm{pH}$ meter: HI98127), surface ( $<20 \mathrm{~cm}$ depth) dissolved oxygen

171 (DO $\mathrm{mg} \mathrm{l}^{-1}$ : recorded using a Mettler Toledo Dissolved Oxygen Meter) and percentage of pond

172 surface covered by submerged macrophytes, emergent macrophytes, floating macrophytes and open

173 water. Pond connectivity (the number of waterbodies hydrologically connected to the sample site) and

174 pond isolation (the number of other waterbodies within $500 \mathrm{~m}$ : Waterkeyn et al., 2008) were recorded

175 using aerial imagery (Google Earth 2015) or maps and through field observations (extensively

176 walking around each sample site during each season to identify any nearby waterbodies). Every effort

177 was made to record all waterbodies within 500m of each pond site, however ephemeral ponds and

178 garden ponds were particularly difficult to identify as many have never been recorded on national

179 maps (OS MasterMap) and are not always visually apparent through inspection of aerial images via

180 Google Earth software, particularly when overgrown or covered by overhanging vegetation. It is

181 therefore acknowledged that some ephemeral and garden ponds will have been omitted.

$183 \quad 2.4$ Statistical Analysis

184 Macroinvertebrate species-abundance data from each season for individual ponds were pooled in the

185 final analysis to provide a measure of alpha diversity within each pond. Rarefaction (Hulbert, 1971)

186 was undertaken in PRIMER 6 to estimate species richness for each pond site based on a given number

187 of individuals drawn randomly from a sample (McCabe and Gotelli, 2000). The least abundant pond

188 study site had 41 individuals and as a result we randomly sampled 41 individuals from each replicate

189 and recorded the rarefied species richness. Such analyses allow for comparisons of species richness

190 based on specific numbers of individuals and as a result avoids biases associated with comparing

191 different sample sizes (Ning and Nielsen, 2011). Before any statistical analyses were undertaken the

192 data were examined to ensure that they complied with the underlying assumptions of parametric

193 statistical tests (e.g., normal distribution). Where these assumptions were not observed (e.g., for

194 macroinvertebrate abundance data) the data were transformed $\left(\log _{10}\right)$. Differences in faunal diversity

195 (abundance and richness: alpha diversity) and environmental variables between floodplain, arable and

196 urban ponds was examined using One-Way Analysis of Variance (ANOVA) and post hoc Tukey tests 
197 in IBM SPSS Statistics (version 21, IBM Corporation, New York) to quantify where differences

198 among different pond types occurred. Gamma diversity was calculated as the total number of aquatic

199 macroinvertebrate taxa recorded among all pond study sites. In addition, estimated gamma diversity

200 was calculated using the Chao1 estimator in PRIMER 6.

201

202 Differences in environmental conditions and aquatic macroinvertebrate communities between pond

203 types were visualised using NMDS with the metaMDS function in the vegan package in R (Okansen

204 et al., 2015) and examined statistically by analysis of similarity (ANOSIM) in PRIMER v6 (Clarke

205 and Gorley, 2006). SIMPER analysis was undertaken in PRIMER 6 to identify those taxa which

206 contributed most to the statistical differences in macroinvertebrate community composition between

207 floodplain, agricultural and urban ponds. Faunal abundance and environmental data were log

208 transformed prior to ANOSIM, SIMPER and NMDS analysis. To examine the heterogeneity of

209 environmental conditions and faunal composition among pond types, analysis of homogeneity of

210 multivariate dispersions (PERMDISP) was undertaken using the vegan package (Okansen et al., 2015)

211 and compared using One-way Analysis of Variance. Bray-Curtis dissimilarity was used for the

212 macroinvertebrate taxa data and Euclidean distance was used for the environmental data for NMDS,

213 ANOSIM and PERMDISP analysis. Redundancy Analysis (RDA) was employed to examine the

214 relationship between macroinvertebrate composition and environmental variables. Prior to analysis,

215 species-abundance data was Hellinger transformed (Legendre \& Gallagher, 2001) and environmental

216 parameters were $\log _{10}$ transformed (to reduce the influence of skew and overcome the effect of their

217 physical units; Legendre \& Birks, 2012). A stepwise selection procedure (forward and backward

218 selection) using permutation-based significance tests (999 permutation) was used to determine the

219 environmental variables that significantly $(\mathrm{p}<0.05)$ explained the variance in pond community

220 composition. Only environmental parameters identified to significantly influence the

221 macroinvertebrate assemblage were included in the final model. RDA was undertaken using the

222 ordistep function in vegan.

223 
224 The conservation value of each pond was examined using the Species Rarity Index (SRI) and the

225 Community Conservation Index (CCI). The rarity value assigned to each macroinvertebrate for the

226 CCI and SRI is based on the UK Joint Nature Conservation Committee (JNCC) designations (see

227 Chadd and Extence, 2004 Appendix 1 and Williams et al., 2003). To calculate SRI, the rarity/threat

228 value assigned to each macroinvertebrate taxa in the pond assemblage is summed and then divided by

229 the number of species recorded in the pond sample (Williams et al., 2003; Rosset et al., 2013). CCI

230 incorporates both the rarity of macroinvertebrate species at a national scale (conservation scores based

231 on published sources and expert opinion) and the community richness (see Chadd and Extence, 2004).

232 CCI can provide the basis for the development for conservation strategies when used in conjunction

233 with knowledge of the habitat requirements of target organisms and communities (Chadd and Extence,

234 2004; Armitage et al., 2012).

235

\section{3. Results}

$237 \quad 3.1$ Environmental characteristics

238 The percentage of surface water shaded (ANOVA $\left.F_{2,90}=6.94 ; \mathrm{p}<0.01\right)$ and the percentage of floating

239 macrophyte coverage (ANOVA $F_{2,90}=8.08$; $\mathrm{p}<0.001$ ) was significantly lower for floodplain ponds

240 than arable or urban ponds (Table 1). Conductivity was significantly higher in arable ponds compared

241 to urban ponds (ANOVA $\mathrm{F}_{2,90}=3.59 ; \mathrm{p}<0.05$; Table 1). Pond isolation (ANOVA $\mathrm{F}_{2,90}=74.19 ; \mathrm{p}<0.001$ )

242 and connectivity (ANOVA $F_{2,90}=26.09 ; \mathrm{p}<0.001$ ) were significantly higher for floodplain ponds than

243 urban or arable ponds (Table 1). There was no significant difference in pond area, pond depth,

244 percentage of the pond covered by emergent or submerged macrophytes, $\mathrm{pH}$ or dissolved oxygen

245 among the three pond types examined.

246

$247 \quad 3.2$ Macroinvertebrate diversity

248 A total of 224 macroinvertebrate taxa were recorded from 21 orders and 68 families (see

249 Supplementary Material Appendix 1) from floodplain (total: 175, range: 5-73), arable (total: 131, 250 range: 9-51) and urban (total: 170, range: 2-61) ponds. Estimated gamma diversity (based on the Chao

2511 estimator) was higher in floodplain (estimated 205 taxa) and urban ponds (estimated 194 taxa) than 
252 in arable ponds (estimated 142 taxa). On average, coleopteran taxa constituted a much greater

253 proportion of taxonomic richness recorded in floodplain ponds (27\%) compared to arable (12\%) and

254 urban ponds (11\%; Fig. 2). Similarly, 16\% of macroinvertebrate taxa recorded from floodplain ponds

255 were hemipteran taxa compared to 9\% in urban ponds and 1\% in arable ponds. Within urban ponds,

256 Diptera larvae formed, a greater proportion of the taxa richness (25\%) than the other two pond types

257 (floodplain: 12\%, arable: 7\%) whilst Ephemeroptera and Hirudinea constituted a greater proportion of

258 taxonomic richness in arable ponds compared to floodplain and urban ponds (Fig. 2).

259 Floodplain ponds (mean taxon richness: 39.2) supported significantly greater macroinvertebrate 260 richness (ANOVA $\left.\mathrm{F}_{2,90}=8.69 ; \mathrm{p}<0.001\right)$ and rarefied species diversity $\left(\mathrm{ANOVA}_{2,90}=11.75\right.$;

$261 \mathrm{p}<0.001$ ) when compared to urban ponds (mean richness: 21.7; Fig. 3a). There was no significant

262 difference in mean macroinvertebrate richness between arable ponds (mean richness: 30.9) and

263 floodplain or urban ponds; although floodplain and urban ponds displayed greater variation in

264 taxonomic richness (Fig. 3a). A total of $69 \%$ of floodplain ponds (24 ponds) and $53 \%$ of arable ponds

265 (8 ponds) supported $>30$ taxa, whereas only $29 \%$ of urban ponds (12 ponds) recorded $>30$ taxa. The

266 greatest taxonomic richness was recorded from a floodplain pond (73 taxa) and all 5 ponds with the

267 greatest alpha macroinvertebrate richness were located on floodplains. No significant difference in the

268 abundance of macroinvertebrates was recorded among floodplain, arable and urban ponds.

269

\section{$270 \quad 3.3$ Faunal heterogeneity}

271 A clear distinction between aquatic macroinvertebrate assemblages in floodplain, urban and arable

272 ponds was observed within the NMDS ordination (Fig. 4a). Floodplain ponds supported significantly

273 different macroinvertebrate assemblages compared to arable and urban ponds (ANOSIM $\mathrm{p}<0.01 \mathrm{r}=$

274 0.19). There was no significant difference in the macroinvertebrate assemblages recorded from urban

275 and arable ponds. The top four macroinvertebrate taxa (identified by SIMPER analysis) driving the

276 difference in differences in community composition between floodplain ponds and arable were

277 Chironomidae (contributing 6.81\% to the dissimilarity), Culicidae (4.96\%) and Chaoboridae (4.64\%)

278 which were recorded in higher abundance in arable ponds and Crangonyx pseudogracilis (4.06\%)

279 which recorded a higher abundance in floodplain ponds. Greater abundances of Chironomidae 
(6.84\%), C. pseudogracilis (6.03\%), Asellus aquaticus (4.96\%) and Oligochaeta in urban ponds were

281 identified by SIMPER as the top 4 macroinvertebrate taxa driving the community heterogeneity

282 between floodplain ponds and urban ponds. The average median distance to the group centroid based on aquatic macroinvertebrate community dissimilarity (faunal multivariate dispersion) was similar among floodplain (0.57), arable (0.52) and urban (0.54) ponds (ANOVA $F_{2,88}=0.91 ; p=0.4 ;$ Fig. 4c) indicating that faunal communities in the three pond types showed similar levels of variation in faunal community composition. Environmental characteristics among floodplain, arable and urban ponds overlapped in the NMDS biplot and ANOSIM did not identify any statistical differences between environmental characteristics for the three pond types (ANOSIM $r=0.041 \mathrm{p}=0.07$; Fig. 4b). The average median distance to the group centroid based on environmental dissimilarity was greater for urban ponds (917.6) than floodplain (479.2) and arable (539.4) ponds, although this was not statistically significant (ANOVA $\mathrm{F}_{2,88}=0.99 ; \mathrm{p}=0.38$; Fig. 4d).

Redundancy analysis identified six significant environmental parameters correlated with the first two

294 RDA axes: connectivity, pond dry months, $\mathrm{pH}$, pond area (all $\mathrm{p}<0.005$ ), percentage pond margin shaded and percentage pond coverage of emergent macrophytes $(\mathrm{p}<0.05)$ (Fig. 5). The RDA axes were highly significant ( $F=3.477 \mathrm{p}<0.001$ ), explaining $26 \%$ of macroinvertebrate community variation on all constrained axes, based on the adjusted $R^{2}$ values (Adjusted $\mathrm{R}^{2}=0.26$ ). Floodplain ponds were separated from urban and agricultural ponds on the first and second axes along gradients associated with connectivity and the number of months the pond dried (Fig. 5). Floodplain ponds were characterized by a greater connectivity, area and ephemerality, whilst urban and agricultural ponds were associated with a greater percentage of the pond margin shaded, greater emergent macrophyte coverage but reduced connectivity and ephemerality (Fig. 5).

\subsection{Conservation value}

305 A total of 13 macroinvertebrate species with a conservation designation were recorded within the

306 ponds examined (Table 2). In all, 23 ponds (24\% of total sample sites) supported one or more 307 invertebrate species with a conservation designation (13 floodplain ponds, 5 urban ponds and 5 arable 
ponds; Table 2). Floodplain ponds supported assemblages with significantly higher Species Rarity

309 Index (SRI) values than urban ponds (ANOVA $F_{2,90}=6.02 \mathrm{p}>0.01$; Table 2). Communities within

310 floodplain ponds had significantly greater Community Conservation Index (CCI) scores than arable

311 and urban ponds (ANOVA $F_{2,90}=12.87 \mathrm{p}>0.001$; Table 2). Macroinvertebrate communities within 6

312 pond sites were of very high conservation value (5 floodplain ponds and 1 arable pond) based on their

313 CCI scores (Fig. 6). In addition, 6 ponds were of high conservation value (6 floodplain ponds). No

314 urban ponds were found to have a high or very high conservation value (Fig. 6). A total of $60 \%$ of

315 ponds across the study region (34\% of floodplain ponds, $60 \%$ of arable ponds and $76 \%$ of urban

316 ponds) supported communities of low or moderate conservation value based on the CCI scores.

\section{4. Discussion}

319 This study has demonstrated that ponds support rich faunal communities of potentially high

320 conservation value in rural and urban settings. Yet operationally, pond conservation remains a

321 significant issue across Europe as a result of the lack of legislative power to protect pond habitats and

322 their associated flora and fauna (Hassall et al. 2016). In Europe, the conservation of ponds currently

323 relies heavily on the presence of rare taxa or records of very high biodiversity in order to designate

324 individual ponds (Hassall et al., 2012). The current system of individual site designation remains an

325 important mechanism for pond conservation as the process can protect species-rich habitats and rare

326 taxa (BRIG 2011). However, the scale at which the current designation of ponds is applied is quite

327 different to the scale at which ponds contribute most towards aquatic biodiversity. This study has

328 demonstrated that faunal richness and conservation value at the alpha scale was highly variable (2-73

329 taxa) but ponds made a significant contribution to biodiversity at the landscape scale. Similar findings

330 were recorded elsewhere in the UK by Williams et al. (2003) and Davies et al. (2008) who found that

331 ponds supported significantly higher macroinvertebrate taxonomic richness at a landscape scale than

332 rivers, lakes and ditches. The small, discrete surface catchments of ponds can result in a wide range of

333 habitats/conditions for macroinvertebrate taxa to colonise and the development of highly diverse and

334 heterogeneous communities at a landscape scale (Williams et al., 2003; Davies et al., 2008); as

335 demonstrated by the high multivariate dispersion observed among pond types in this study. High 
macroinvertebrate community heterogeneity can be further attributed to the increased influence of

337 stochastic events (related to dispersal limitation or priority effects) on small water bodies (Scheffer et

338 al., 2006). As a result, pond conservation strategies need to be developed and applied at the

339 landscape-scale to provide the greatest potential benefit to aquatic biodiversity (Davies et al., 2008;

340 Sayer, 2014). Temporal studies of pond biodiversity have also demonstrated that the conservation

341 value of individual ponds fluctuates over time as rare taxa present during one year may be absent the

342 next (Greenwood and Wood., 2003; Hassall et al., 2012). This further suggests moving away from the

343 designation of individual ponds towards the conservation of pond clusters and 'pondscapes' to

344 provide the greatest long term conservation benefit for biodiversity (Hassall et al., 2012).

345

346 Floodplain ponds supported heterogeneous communities and were of a significantly higher

347 conservation value compared to urban ponds in this study. This probably reflects floodplain ponds

348 location in semi-natural landscapes (nature reserves), the resulting management practices (designed to

349 benefit biodiversity), reduced shading (Sayer et al., 2012), their high connectivity to other waterbodies

350 and reduced anthropogenic disturbances. In contrast, urban ponds are located in structurally complex

351 and fragmented urban landscapes with lower connectivity (Noble and Hassall, 2014). When combined

352 with the high levels of anthropogenic disturbance (e.g., urban runoff/pollution) and management

353 practices (for purposes other than biodiversity: Briers, 2014), this can result in very different

354 macroinvertebrate communities to floodplain and arable ponds. Floodplain pond communities

355 typically had good water quality and high coverage of emergent and submerged macrophytes,

356 providing suitable conditions for taxa of high conservation value and a dominance of Coleoptera and

357 Hemiptera taxa, while high connectivity to other waterbodies also promoted easy dispersal between

358 them. Urban ponds were dominated by Diptera larvae, which have been recorded to colonise isolated

359 urban ponds (Gaston et al., 2005) and many have broad tolerances to adverse environmental

360 conditions (Carew et al., 2007; Serra et al., 2016). Although environmental conditions were widely

361 dispersed in the NMDS biplot they were not found to be statistically different between floodplain,

362 agricultural and urban ponds. This most likely reflects the variability in environmental conditions

363 across all three ponds types but may also reflect the limited number of environmental variables 
recorded. Further detailed examination of hydrochemical data, substrate type and bank type would

365 have added greater information regarding environmental conditions within the ponds examined and

366 the key environmental variables driving pond community composition to (26\% of variation was

367 explained by the RDA, indicating that other unmeasured abiotic variables influence community structure) and should be considered in future investigations.

370 Biodiversity conservation at a landscape scale commonly relies on designated areas or reserves to

371 protect individual species and habitats (Briers, 2002; Mcdonald et al., 2008). In this study, the ponds

372 of greatest biodiversity and conservation value were located on floodplain meadows specifically

373 identified as nature conservation areas providing protection from anthropogenic disturbance. Nature

374 reserves can help deliver landscape-scale (pondscape) conservation, especially on lowland floodplains,

375 providing a highly connected freshwater landscape (incorporating rivers, lakes, ponds, ditches and

376 wetlands) supporting high numbers of rare taxa and allowing organisms to disperse widely and

377 colonise different aquatic habitats (Cottenie, 2005; Williams et al., 2008; Sayer, 2014). However,

378 increasing anthropogenic land cover is projected to threaten the flora and fauna within many of these

379 protected areas (Guneralp and Seto, 2013). The conservation of species or habitats should not depend

380 exclusively on designated sites (Chester and Robson, 2013; Baudron and Giller, 2014), and

381 biodiversity conservation should be opportunistically enhanced wherever possible. Many ponds

382 provide rich and diverse habitats outside of protected areas (as demonstrated in this study by urban

383 ponds similar diversity to floodplain ponds at the landscape scale) suitable for freshwater landscape-

384 scale conservation. In the UK, the Wildlife Trusts are incorporating a 'living landscape approach'

385 which provides landscape-scale conservation outside of conservation areas, restoring links and

386 corridors through the creation of meadows, hedges and ponds between wildlife sites in urban and rural

387 landscapes to reconnect large areas of land separated in the last 100-200 years to enhance biodiversity

388 and create ‘wildlife-friendly’ environments (The Wildlife Trusts, 2014).

390 Whilst there is consensus regarding the value of undertaking pond conservation at the

391 network/landscape scale, there is debate about how best to achieve this (Sayer et al., 2012). Currently 
the focus is on the building of new high quality ponds in response to pond loss and to increase pond connectivity. For example, the Million Ponds Project is a 50-year project which seeks to create a

394 network of 500,000 (in addition to the existing 500,000 ponds in the UK) new clean water ponds across the UK (Freshwater Habitats Trust, 2014). However, management and restoration can provide a complimentary conservation strategy alongside pond creation to mitigate the impact of urbanisation and land use intensification and restore and improve aquatic biodiversity of the existing pond resource

398 (Oertli et al., 2005; Sayer et al., 2013; Hassall, 2014). Agri-environment schemes (AES) provide

399 financial compensation to farmers who incorporate measures which promote and benefit biodiversity, 400 including maintaining pond habitats on agricultural land (Kleijn and Sutherland, 2003; Davies et al., 401 2008). Despite this, farmland pond numbers continue to decline and many agricultural/arable ponds are typically left unmanaged resulting in degraded ponds with poor habitat quality (e.g., high levels of pond shading), which over time can fill with sediment (Sayer et al., 2012). Active management such as sediment, tree and scrub removal is required in many agricultural areas to improve the condition of the resource for biodiversity and potentially create a culture of care and pride in relation to agricultural ponds (Sayer et al., 2012; Riordan et al., 2015). The agricultural ponds in this study had lower landscape-scale diversity than the other two pond types, reflecting their lack of management (most were at a late successional stage) and location in a homogenous, intensively farmed landscape (Boothby, 2003; Sayer et al., 2012). Agricultural conservation initiatives (such as AES) may be most beneficial when undertaken at smaller spatial scales (pond clusters) than larger scales, as the most effective locations can be targeted which will provide the maximum diversity for the economic and

412 effort input (Davies et al., 2009).

414 For ponds located in agricultural or urban landscapes where their primary function is not for 415 biodiversity, the application of reconciliation ecology (Rosenzweig, 2003) as a management/conservation tool may be the most beneficial way to improve biodiversity at larger 417 geographical scales. Reconciliation ecology suggests ways to modify and diversify anthropogenically418 created habitats to improve their biological conditions whilst maintaining the effectiveness of their 419 primary function (Rosenzweig, 2003). Previous research has shown that only small changes to current 
management techniques for freshwaters in urban and agricultural landscapes is likely to significantly

421 improve faunal richness in these anthropogenically-dominated landscapes (Twisk et al., 2000; Twisk

422 et al, 2003; Hill et al., 2015). Reconciliation ecology as a management/conservation strategy for

423 ponds has the potential to meet the needs of humans (e.g., flood alleviation, water storage) and support the conservation of biological diversity in landscapes subject to anthropogenic processes associated with urbanisation (Chester and Robson, 2013; Moyle, 2014). In addition, raising awareness of the contribution of urban ponds to biodiversity may also play a key role in influencing and shaping

427 the perceptions of land owners, local government and general public regarding 1) the importance of 428 ponds for freshwater conservation, 2) the urban-rural landscape as a functional interconnected system and 3) the wider conservation agenda. However, complications surrounding land ownership, increasing development on urban green space and the economic value of urban land may make landscape scale conservation in urban and peri-urban areas difficult to navigate and implement for 432 policy makers.

\section{4.1 Conclusion}

435 This study has demonstrated that floodplain ponds supported the greatest macroinvertebrate diversity of the three land uses examined. However, ponds associated with arable and urban land uses also provide habitats of rich macroinvertebrate diversity and high conservation value. Ponds contribute significantly to biodiversity at a landscape scale and focussing conservation efforts at this scale is

439 likely to be the most ecologically beneficial and sustainable way to conserve pond networks, promote 440 regional biodiversity across rural and urban landscapes and increase the connectivity between ponds

441 and other freshwater habitats. While specially designated areas for conservation remain an important 442 strategy for biodiversity conservation, ponds provide aquatic habitat outside of protected areas 443 suitable for freshwater landscape scale conservation. Pond conservation at the landscape scale may be 444 best served by a combination of pond management and the creation of new ponds, which will greatly 445 increase the numbers of high quality pond habitats and provide a range of pond types and 446 environmental conditions suitable for a wide range of flora and fauna. Ponds need to be incorporated 447 in more detail into freshwater conservation legislation. In particular, there is a need for an integrated 
448 approach to freshwater conservation incorporating ponds with other freshwaters to provide an

449 efficient and sustainable way of protecting freshwater biological diversity.

450

\section{Acknowledgements}

452 We would like to thank Charnwood Borough Council, Loughborough University, Leicestershire and

453 Rutland Wildlife Trust, Leicestershire County Council and the home and farm owners that granted 454 access to ponds located on their land. Thanks must go to Danielle Ashdown, Stuart Ashby and Barry

455 Kenny for their help and assistance with field and laboratory work. This research would not have been 456 possible without the support of the Loughborough University Graduate School Studentship in the 457 Department of Geography.

458

459 References

460 Armitage, P. D., Hawczak, A., Blackburn, J. H., 2012. Tyre track pools and puddles - Anthropogenic 461 contributors to aquatic biodiversity. Limnetica 42, 254-263.

462 Baudron, F., Giller, K. E., 2014. Agriculture and nature: Trouble and strife? Biol. Conserv. 170, 232463245

464 Biggs, J., Fox, G., Whitfield, M., Williams. P., 1998. A guide to the methods of the National Pond 465 Survey. Pond Action, Oxford.

466 Biggs, J., Williams, P., Whitfield, M., Nicolet, P., Brown, C., Hollis, J., Arnold, D., Pepper, T., 2007.

467 The Freshwater biota of British agricultural landscapes and their sensitivity to pesticides. Agric.

468 Ecosyst. Environ. 122, 137-148

469 Biggs, J., Williams, P., Whitfield, M., Nicolet, P., Weatherby, A., 2005. 15 years of pond assessment 470 in Britain: results and lessons learned from the work of pond conservation. Aquat. Conserv. Mar.

471 Freshwat. Ecosyst. 15, 693-714.

472 Boothby, J., 2003. Tackling degradation of a seminatural landscape: options and evaluations. Land

473 Degradation and Development 14, 227-243.

474 Briers, R. A., 2002. Incorporating connectivity into reserve selection procedures. Biol. Conserv. 103, $475 \quad 77-83$. 
476 Briers, R. A. 2014. Invertebrate communities and environmental conditions in a series of urban

477 drainage ponds in Eastern Scotland: implications for biodiversity and conservation value of SUDS.

478 Clean - Soil, Air, Water 4, 193-200.

479 BRIG., 2011. UK Biodiversity Action Plan Priority Habitat Descriptions. Peterborough: JNCC.

480 Carew, M. E., Pettigrove, V., Cox, R. L. and Hoffmann, A. A. 2007. The response of Chironomidae to 481 sediment pollution and other environmental characteristics in urban wetlands. Freshwater Biol. 52, $482 \quad 24444-2462$.

483 Chadd, R., Extence, C., 2004. The conservation of freshwater macroinvertebrate populations: a

484 community based classification scheme. Aquat. Conserv.: Mar. Freshwat. Ecosyst. 14, 597-624.

485 Céréghino, R., Ruggiero, A., Marty, P., Angélibert, S., 2008. Biodiversity and distribution patterns of 486 freshwater invertebrates in farm ponds of a south-western French agricultural landscape.

487 Hydrobiologia 597, 43-51.

488 Céréghino, R., Boix, D., Cauchie, H., Martens, K., Oertli, B., 2014. The ecological role of ponds in a 489 changing world. Hydrobiologia 723, 1-6.

490 Chester, E. T., Robson, B. J., 2013. Anthropogenic refuges for freshwater biodiversity: Their

491 ecological characteristics and management. Biol. Conserv. 166, 64-75.

492 Clarke, K. R., Gorley, R. N., 2006. PRIMER v6: User Manual/Tutorial. PRIMER E-Ltd: Plymouth, 493 UK.

494 Cottenie, K., 2005. Integrating environmental and spatial processes in ecological community 495 dynamics. Ecol. Lett. 8, 1175-1182.

496 Coutts, A. M., Tapper, N. J., Beringer, J., Loughnan, M., Demuzere, M., 2012.Watering our cities: the 497 capacity for water sensitive urban design to support urban cooling and improve human thermal 498 comfort in the Australian context. Prog. Phys. Geog. 1-27.

499 Davies, B. R., Biggs, J., Williams, P., Whitfield, M., Nicolet, P., Sear, D., Bray, S., Maund, S., 2008. 500 Comparative biodiversity of aquatic habitats in the European agricultural landscape. Agric. Ecosyst. 501 Environ. 125, 1-8. 
502 Davies, B., Biggs, J., Williams, P., Thompson, S., 2009. Making agricultural landscapes more

503 sustainable for freshwater biodiversity: a case study from southern England. Aquat Conserv. Mar.

504 Freshwat. Ecosyst. 19, 439-447.

505 Downing, J. A., Prairie, Y. T., Cole, J. J., Duartem C. M., Tranvik, L. J., Striegel, R. G., McDowell, 506 W. H., Kortelainen, P., Caraco, N. F. Melack, J. M., Middelburgh, J. J., 2006. The global abundance 507 and size distribution of lakes, ponds and impoundments. Limnol. Oceanogr. 51, 2388-2397.

508 Downing, J. A., Cole, J. J., Middelburg, J. J., Striegl, R. G., Duarte, C. M., Kortelainen, P., Prairie, Y.

509 T., Laube, K. A., 2008. Sediment organic carbon burial in agriculturally eutrophic impoundments

510 over the last century. Global Biogeochem. Cycles. 22, GB1018.

511 Dudgeon, D. et al., 2006. Freshwater biodiversity: importance, threats, status and conservation 512 challenges. Biol. Rev. 81, 163-182.

513 EC., 2000. Directive 2000/60/EC of the European Parliament and of the Council of 23 October 2000

514 establishing a framework for Community action in the field of water policy, 22/12/2000. Official

515 Journal. 327/1, 1-73.

516 Freshwater Habitats Trust., 2014. Accessible at; http://freshwaterhabitats.org.uk/wp-

517 content/uploads/2013/08/MPP-Y4-REPORT-final low-res.pdf [last accessed: 04/02/2016]

518 Gaston, K. J., Smith, R. M., Thompson, K., Warren, P. H., 2005. Urban domestic gardens (II):

519 experimental test of methods for increasing biodiversity. Biodivers. Conserv. 14, 395-413.

520 Gioria, M., Schaffers, A., Bacaro, G., Feehan, J., 2010. The conservation value of farmland ponds:

521 predicting water beetle assemblages using vascular plants as a surrogate group. Biol. Conserv. 143,

$522 \quad 1125-1133$.

523 Gledhill, D. G., James, P., Davies, D. H., 2008. Pond density as a determinant of aquatic species

524 richness in an urban landscape. Landsc. Ecol. 23, 1219-1230.

525 Greenwood, M. T., Wood, P. J., 2003. Effects of seasonal variation in salinity on a population of

526 Enochrus bicolor Fabricius 1792 (Coleoptera: Hydrophilidae) and implications for other beetles of

527 conservation interest. Aquat. Conserv. Mar. Freshwat. Ecosyst. 13, 21-34.

528 Guneralp, B., Seto, K. C., 2013. Futures of global urban expansion: uncertainties and implications of 529 biodiversity conservation. Environ. Res. Lett. 8, 1-10. 
530 Hassall, C., Anderson, S., 2015. Stormwater ponds can contain comparable biodiversity to unmanaged

531 wetlands in urban areas. Hydrobiologia 745, 137-149.

532 Hassall, C., Hollinshead, J., Hull, A., 2012. Temporal dynamics of aquatic communities and 533 implications for pond conservation. Biodivers. Conserv. 21, 829-852.

534 Hassall, C., 2014. The ecology and biodiversity of urban ponds. WIREs Water 1, 187-206.

535 Hassall, C., Hill, M. Gledhill, D., Biggs, J., 2016. The ecology and management of urban pondscapes.

536 In: Francis, R., Millington, J. D. A., Chadwick , M. A., (ed.) 2016. Urban landscape ecology: Science, 537 Policy and Practice, Routledge:Abingdon, UK.

538 Hill, M. J., Mathers, K. L., Wood, P. J., 2015. The aquatic macroinvertebrate biodiversity of urban 539 ponds in a medium-sized European town (Loughborough, UK). Hydrobiologia 760, 225-238.

540 Hinden, H., Oertli, B., Menetrey, N., Sager, L., Lachavanne, J., 2005. Alpine pond biodiversity: what

541 are the related environmental variables. Aquat. Conserv.: Mar. Freshwat. Ecosyst. 15, 613-624.

542 Hurlbert, S. H., 1971. The nonconcept of species diversity: a critique and alternative parameters.

543 Ecology 52, 577-585.

544 Hull, A. P., 1997. The pond life project: a model for conservation and sustainability, in Boothby, J.

545 (ed.) 1997. British Pond Landscapes: Actions for Protection and Enhancement, Proceedings of the UK 546 Conference of the Pond Life Project. Pond Life Project: Liverpool, 101-109.

547 Kleijn, D., and Sutherland, W. J. 2003. How effective are European agri-environment schemes in 548 conserving and promoting biodiversity. J. Appl. Ecol. 40, 947-969.

549 Le Viol, I., Mocq, J. Julliard, R., Kerbiriou, C., 2009. The contribution of motorway stormwater 550 retention ponds to the biodiversity of aquatic macroinvertebrates. Biol. Conserv. 142, 3163-3171.

551 McCabe, D. J., Gotelli, N. J., 2000. Effects of disturbance frequency, intensity and area on 552 assemblages of stream macroinvertebrates. Oecologia 124, 270-279.

553 Mcdonald, R. I., Kareiva, P., Forman, R. T. T., 2008. The implications of current and future 554 urbanization for global protected areas and biodiversity conservation. Biol. Conserv.141, 1695-1703. 555 Met Office., 2015. Accessible at: http://www.metoffice.gov.uk/public/weather/climate/gcrhhqqzs [last 556 accessed 2 November 2015]. 
557 Moyle, P. B., 2014. Novel aquatic ecosystems: the new reality for streams in California and other

558 Mediterranean climate regions. Riv. Res. Appl. 30, 1335-1344.

559 Ning, N. S. P., Nielsen, D. L., 2011. Community structure and composition of microfaunal egg bank 560 assemblages in riverine floodplain sediments. Hydrobiologia 661, 211-221.

561 Noble, A., Hassall, C., 2014. Poor ecological quality of urban ponds in northern England: causes and 562 consequences. Urban Ecosyst. 1-14.

563 Oertli, B., Biggs, J., Céréghino, R., Grillas, P., Joly, P., Lachavanne, J., 2005. Conservation and 564 monitoring of pond biodiversity: introduction. Aquat. Conserv.: Mar.Freshwat. Ecosyst. 15, 535-540.

565 Oertli, B., Céréghino, R., Hull, A., Miracle, R., 2009. Pond conservation: from science to practice. 566 Hydrobiologia 634, 1-9.

567 Oksanen, J., Blanchet, F.G., Kindt, R., Legendre, P., Minchin, P. R., O'Hara, R.B., Simpson, G.L., 568 Solymos, Stevens, H.H., Wagner, H., 2015. Vegan: Community Ecology Package. R package version 569 2.3-1. [Accessible at http://CRAN.R-project.org/package=vegan]

570 Riordan, P., Feber, R. E., Raebel, E. M., Johnson, P. J., Macdonald, D. W., 2015. From science to 571 practice: delivering conservation across the landscape. In Macdonald, D. W., Feber, R. E., (ed.) 2015. 572 Wildlife Conservation on Farmland Volume 2: Conflict in the Countryside. Oxford University Press: 573 Oxford.

574 Rosenzweig, M. L., 2003. Reconciliation ecology and the future of species diversity. Oryx 37, 194575205.

576 Rosset, V., Simaika, J. P., Arthaud, F., Bornette, G., Vallod, D., samways, M. J., Oertli, B., 2013.

577 Comparative assessment of scoring methods to evaluate the conservation value of pond and small lake 578 biodiversity. Aquat. Conserv. Mar. Freshwat. Ecosyst. 23, 23-36.

579 Sayer, C. D., 2014. Conservation of aquatic landscapes: ponds, lakes, and rivers as integrated 580 systems. WIREs Water 1, 573-585.

581 Sayer, C., Andrews, K., Shiland, E., Edmonds, N., Edmonds-Brown, R., Patmore, I., Emson, D., 582 Axmacher, J., 2012. The role of pond management for biodiversity conservation in an agricultural 583 landscape. Aquat. Conserv. 22, 626-638. 
584 Scheffer, M., Van Geest, G. J., Zimmer, K., Jeppesen, E., Søndergaard, M., Butler, M. G., Hanson, M.

585 A., Declerck, S., De Meester, L., 2006. Small habitat size and isolation can promote species richness:

586 second-order effects on biodiversity in shallow lakes and ponds. Oikos 112, 227-231.

587 Serra, S. R. Q., Cobo, F., Graca, M. A. S., Doledec, S., Feio, M. J., 2016. Synthesising the trait

588 information of European Chironomidae (Insect: Diptera): towards a new database. Ecol. Indic. 61, $589 \quad 282-292$.

590 Twisk, W., Noordervliet, M.A.W., ter Keurs, W. J., 2000. Effects of ditch management on caddisfly,

591 dragonfly and amphibian larvae in intensively farmed peat areas. Aquat. Ecol. 34, 397-411.

592 Twisk, W., Noordervliet, M.A.W., ter Keurs, W. J., 2003. The nature value of the ditch vegetation in 593 peat areas in relation to farm management. Aquat. Ecol. 37, 191-209.

594 Usio, N., Imada, M., Nakagawa, M., Akasaka, M., Takamura, N., 2013. Effects of pond draining on 595 biodiversity and water quality of farm ponds. Conserv. Biol. 27, 1429-1438.

596 Waterkeyn, A., Grillas, P., Vanschoenwinkel, B., Brendonck, L., 2008. Invertebrate community

597 patterns in Mediterranean temporary wetlands along hydroperiod and salinity gradients. Freshwater

598 Biol. 53, 1808-1822

599 The Wildlife Trusts., 2014. A living landscape: A call to restore the UK’s battered ecosystems, for 600 wildlife and people. Accessible at: http://www.wildlifetrusts.org/sites/wt-

601 main.live.drupal.precedenthost.co.uk/files/A\%20Living\%20Landscape\%20report\%202009\%20update 602 .pdf [Last accessed: 04/02/2016].

603 Williams, P., Biggs, J., Crowe, A., Murphy, J., Nicolet, P., Meatherby, A., Dunbar, M., 2010.

604 Countryside survey report from 2007, Technical report No 7/07 Pond Conservation and NERC/Centre 605 for Ecology and Hydrology, Lancaster.

606 Williams, P., Whitfield, M., Biggs, J., 2008. How can we make new ponds biodiverse? A case study 607 monitored over seven years. Hydrobiologia 597, 137-148.

608 Williams, P. Whitfield, M., Biggs, J., Bray, S., Fox, G., Nicolet, P., Sear, D., 2003. Comparative 609 biodiversity of rivers, streams, ditches and ponds in an agricultural landscape in Southern England. 610 Biol. Conserv. 115, 329-341. 
611 Wood, P.J., Greenwood, M. T., Agnew, M. D., 2003. Pond biodiversity and habitat loss in the UK.

612 Area 35, 206-216.

613 Zacharais, I., Dimitirou, E. Dekker, A., Dorsman, E., 2007. Overview of temporary ponds in the

614 Mediterranean region: Threats, management and conservation issues. J. Env. Biol. 28, 1-9. 


\section{Tables}

616 Table 1 - Summary table of environmental characteristics for urban, floodplain and arable ponds. SWS: pond surface area shaded, EM: emergent macrophytes,

617 SM: submerged macrophytes, FM: floating macrophytes, COND: conductivity (in microS $\mathrm{cm}^{-1}$ ), Iso: pond isolation and Connect: pond connectivity.

\begin{tabular}{|c|c|c|c|c|c|c|c|c|c|c|c|}
\hline & & Area $\left(\mathrm{m}^{2}\right)$ & Depth $(\mathrm{cm})$ & SWS (\%) & EM (\%) & SM (\%) & FM (\%) & $\mathrm{pH}$ & COND & Iso & Connect \\
\hline \multirow{4}{*}{$\begin{array}{l}\text { Urban } \\
(n=41)\end{array}$} & Mean & 780.3 & 67.5 & 17.5 & 23.0 & 21.1 & 15.8 & 7.8 & 501.3 & 4 & 0.5 \\
\hline & Standard Error & 301.3 & 10.3 & 4.5 & 4.6 & 3.7 & 4.1 & 0.1 & 43.8 & 0.4 & 0.2 \\
\hline & Min & 0.8 & 4 & 0 & 0 & 0 & 0 & 6.3 & 63.7 & 0 & 0 \\
\hline & Max & 9309 & $>200$ & 100 & 100 & 90 & 96.7 & 9.8 & 1322 & 9 & 3 \\
\hline \multirow{4}{*}{$\begin{array}{l}\text { Floodplain } \\
(\mathrm{n}=35)\end{array}$} & Mean & 376.8 & 52.5 & 6.1 & 21.5 & 29.1 & 2.1 & 8 & 613.7 & 16 & 6 \\
\hline & Standard Error & 154 & 6.5 & 3.3 & 4.4 & 4.5 & 1 & 0.1 & 50.7 & 1.1 & 1 \\
\hline & Min & 10.3 & 8 & 0 & 0 & 0 & 0 & 6.4 & 80 & 7 & 0 \\
\hline & $\operatorname{Max}$ & 5256 & $>200$ & 93.3 & 86.7 & 100 & 30.3 & 9.1 & 1494 & 30 & 14 \\
\hline \multirow{4}{*}{$\begin{array}{c}\text { Arable } \\
(n=15)\end{array}$} & Mean & 432.5 & 71.6 & 22.4 & 29.4 & 13.8 & 10.1 & 7.9 & 728.3 & 6 & 0 \\
\hline & Standard Error & 295.8 & 15.1 & 8.5 & 7.5 & 3.2 & 3.8 & 0.1 & 78.6 & 0.7 & 0.1 \\
\hline & Min & 24.4 & 12 & 0 & 0 & 0 & 0 & 7.4 & 205.0 & 0 & 0 \\
\hline & Max & 4566 & $>100$ & 100 & 86.7 & 37.3 & 55.0 & 8.3 & 1326.7 & 9 & 2 \\
\hline \multirow{4}{*}{$\begin{array}{l}\text { Region } \\
(n=91)\end{array}$} & Mean & 567.8 & 62.4 & 13.9 & 23.6 & 23.0 & 9.6 & 7.9 & 582.0 & 9 & 3 \\
\hline & Standard Error & 155.8 & 5.8 & 2.8 & 2.8 & 2.5 & 2.1 & 0.1 & 31.5 & 7.1 & 4.8 \\
\hline & Min & 0.8 & 4 & 0 & 0 & 0 & 0 & 6.3 & 63.7 & 0 & 0 \\
\hline & Max & 9309 & $>100$ & 100 & 100 & 100 & 96.7 & 9.8 & 1494 & 30 & 14 \\
\hline
\end{tabular}


618 Table 2 - Mean macroinvertebrate Community Conservation Index (CCI) scores, mean Species Rarity

619 Index Scores (SRI) and the aquatic macroinvertebrate taxa with a conservation designation recorded

620 from floodplain, arable and urban ponds.

621

\begin{tabular}{|c|c|c|c|}
\hline & Floodplain & Arable & Urban \\
\hline Mean CCI & 13.14 & 8.97 & 6.20 \\
\hline Mean SRI & 1.093 & 1.067 & 1.039 \\
\hline $\begin{array}{l}\text { Number of ponds } \\
\text { supporting at least one } \\
\text { taxa with a conservation } \\
\text { designation (/ total) }\end{array}$ & $13(/ 35)$ & $5(/ 15)$ & $5(/ 41)$ \\
\hline $\begin{array}{l}\text { Taxa with conservation } \\
\text { designation }\end{array}$ & $\begin{array}{l}\text { Berosus luridus } \\
\text { Ilybius subaeneus } \\
\text { Agabus conspersus } \\
\text { Hygrotus nigrolineatus } \\
\text { Rhantus frontalis } \\
\text { Helophorus dorsalis } \\
\text { Paracymus scutellaris }\end{array}$ & $\begin{array}{l}\text { Sisyra terminalis } \\
\text { Agabus conspersus } \\
\text { Rhantus frontalis } \\
\text { Helophorus dorsalis } \\
\text { Helophorus strigifrons }\end{array}$ & $\begin{array}{l}\text { Coenagrion pulchellum } \\
\text { Gyrinus distinctus } \\
\text { Agabus uliginosus } \\
\text { Helochares punctatus } \\
\text { Helophorus strigifrons }\end{array}$ \\
\hline
\end{tabular}

622

623

624

625

626

627

628

629

630

631

632

633 
635 Figure 1

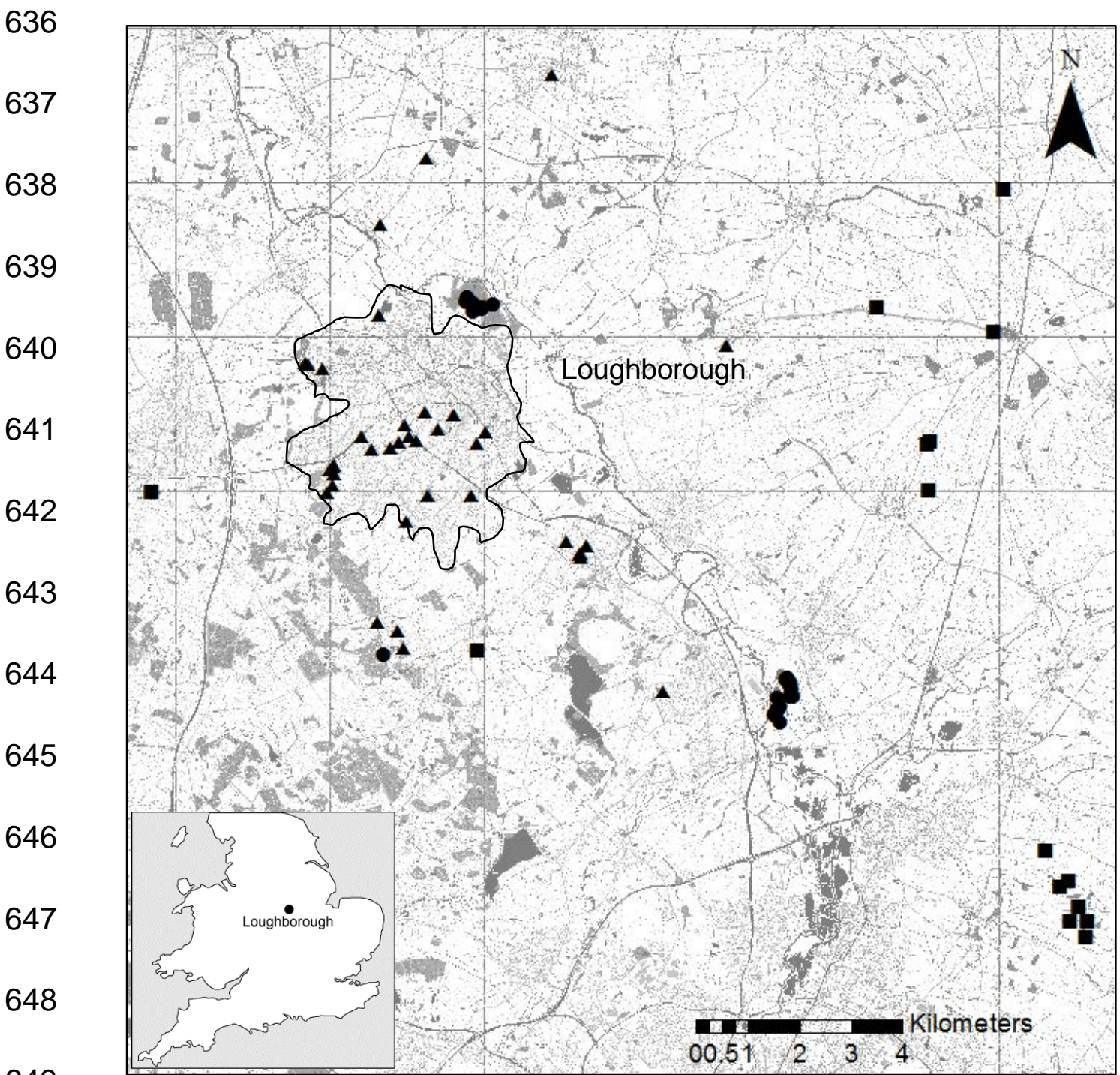

650

651 Figure 1 - Location of the 91 ponds (35 floodplain, 41 urban and 15 agricultural ponds) examined in

652 Leicestershire, UK and its location in relation to England and Wales (inset). Triangles = urban ponds, 653 circles $=$ floodplain ponds and squares $=$ agricultural ponds 
657 Figure 2

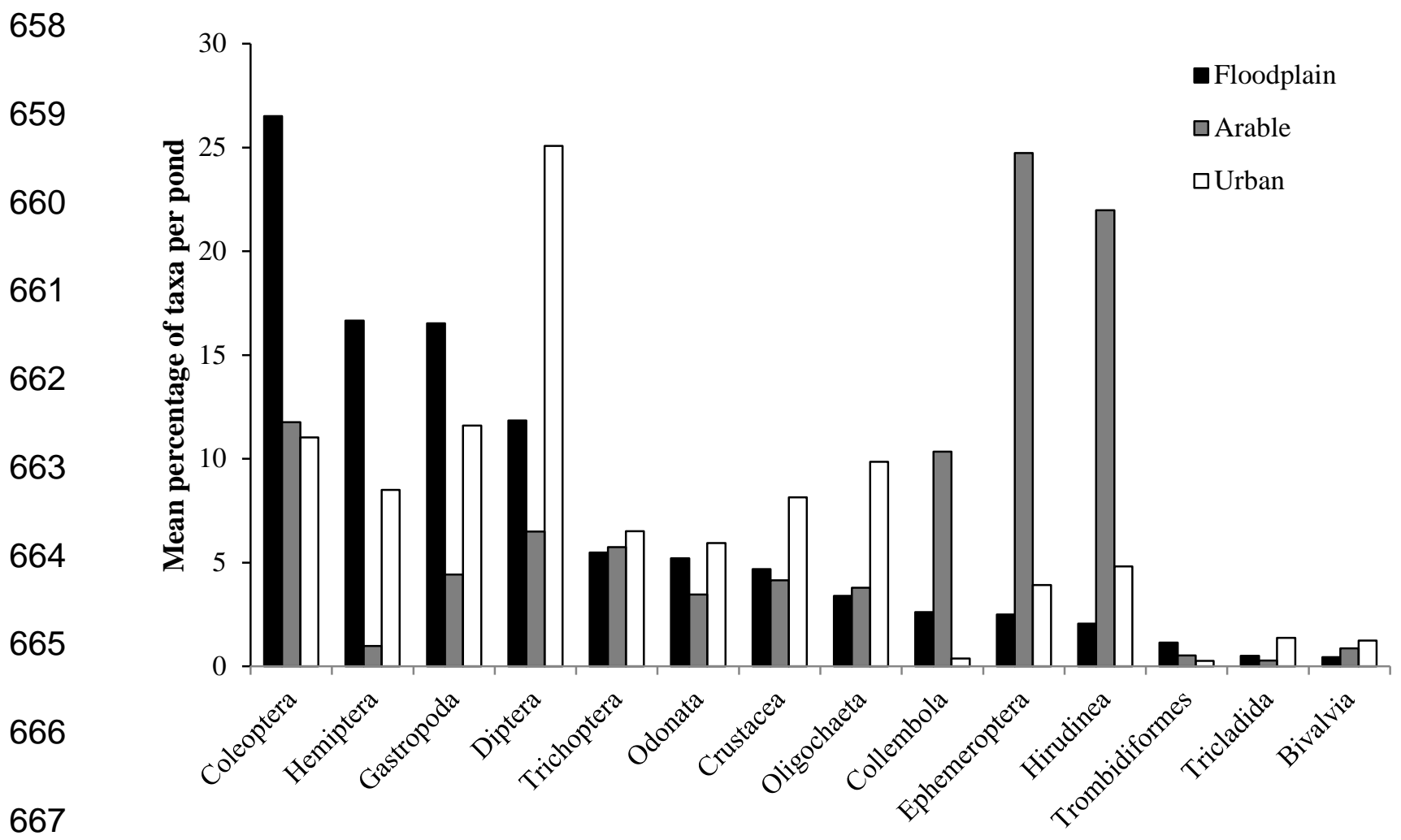

668 Figure 2 - Mean percentage of taxa per pond for selected macroinvertebrate groups in floodplain,

669 arable and urban ponds.

670

671

672

673

674

675

676

677

678

679 
Figure 3

681

682

683

684

685

686

687

688

689

690

691

692

693

694

695

696

697

698

699

700

701

702

703

704

705

706

707

708
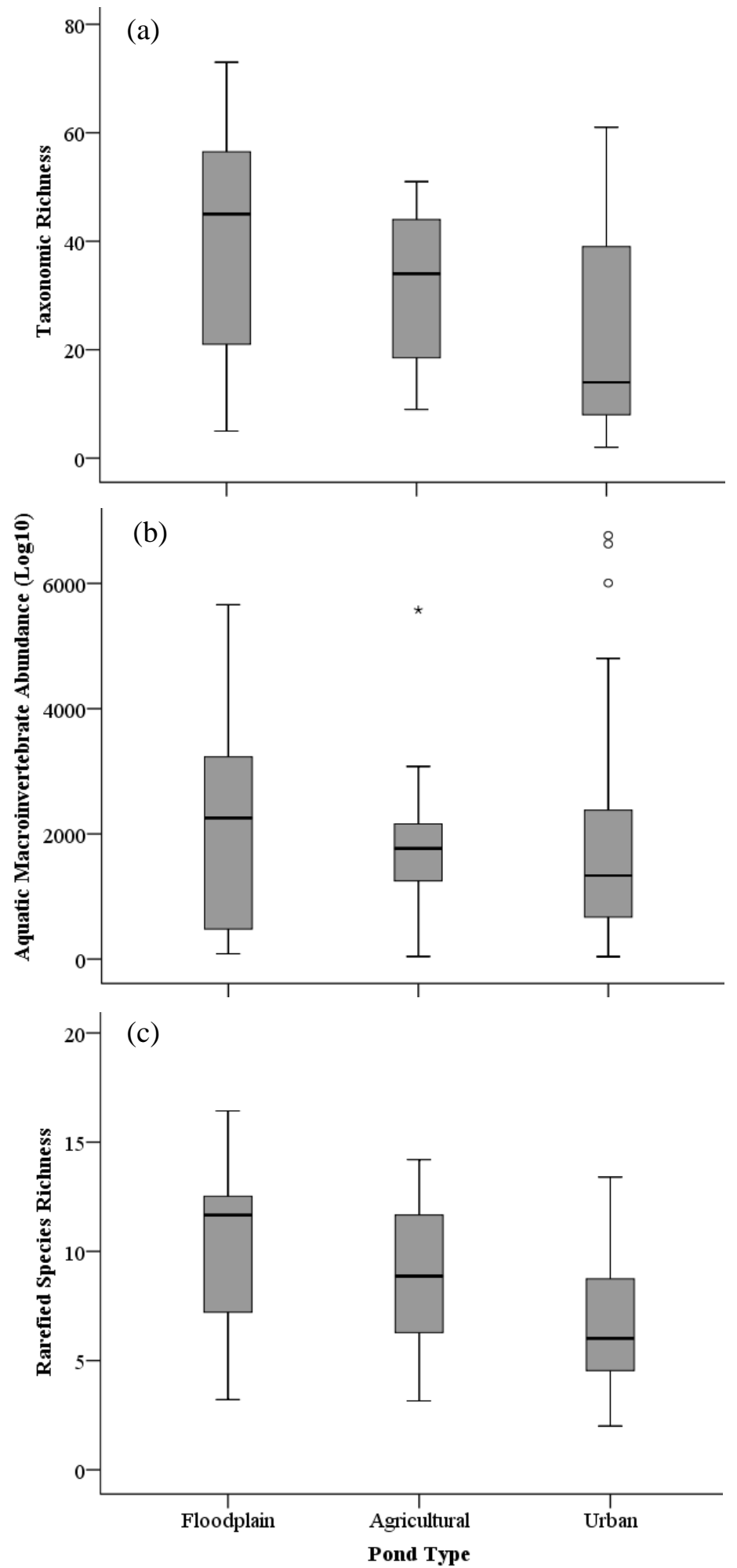

709 Figure 3 - Abundance (a), taxonomic richness (b) and rarefied species richness (c) of

710 macroinvertebrates recorded from floodplain, arable and urban ponds. Open circle = outlier defined

711 on the basis of being greater than 1.5 times the interquartile range, open square $=$ outlier defined on

712 the basis of being greater than 3 times the interquartile range. 
713 Figure 4
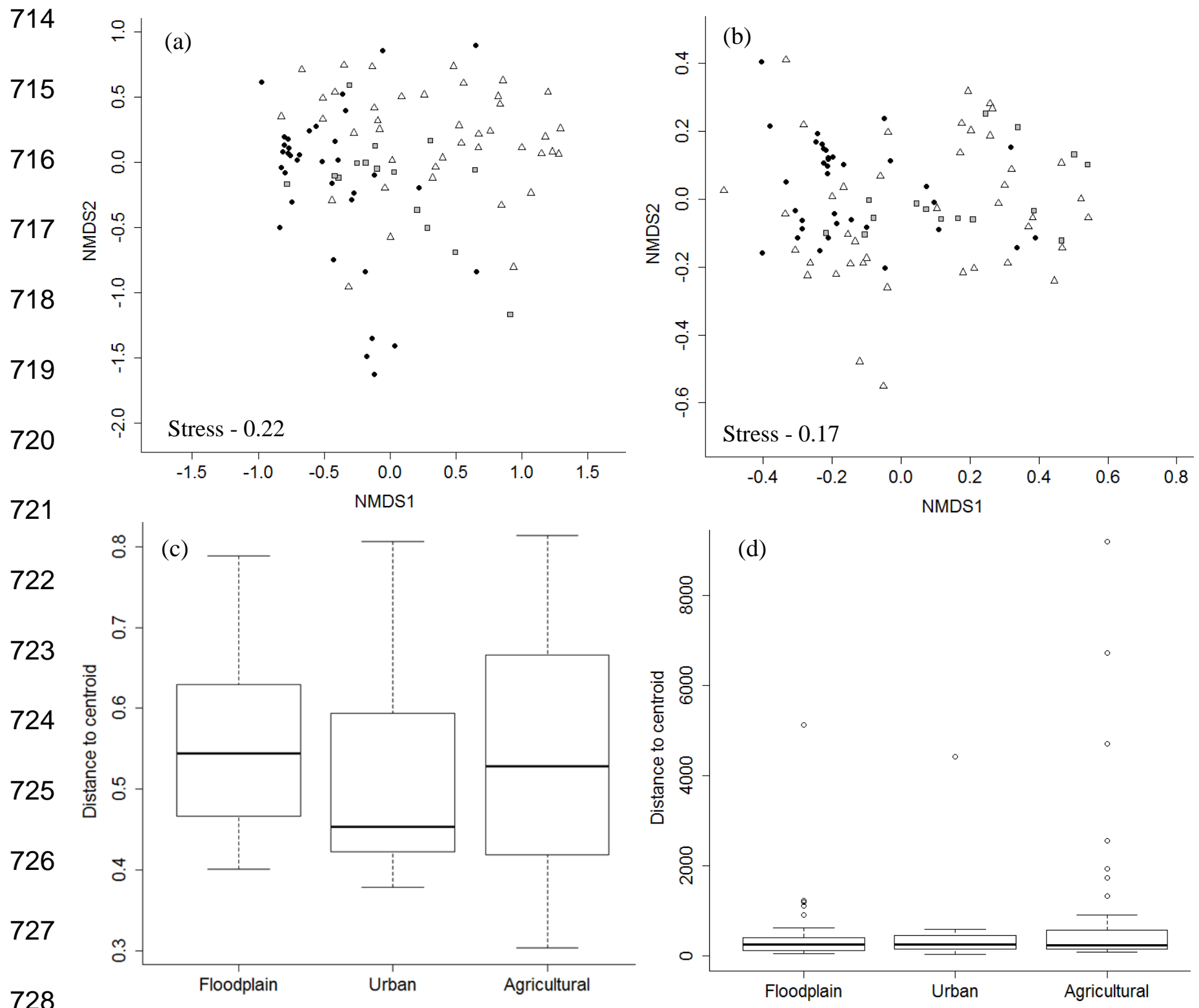

729 Figure 4 - Non-Metric Multidimensional scaling plots of variation in (a) macroinvertebrate

730 communities and (b) environmental characteristics (black symbols - urban ponds, grey squares -

731 arable ponds and open triangles - floodplain ponds) and boxplots of multivariate dispersion distances

732 for (c) macroinvertebrate communities and (d) environmental conditions from the three pond types. 
Figure 5

737

738

739

740

741

742

743

744

745

746

747

748

749<smiles>[Li][CaH]</smiles>

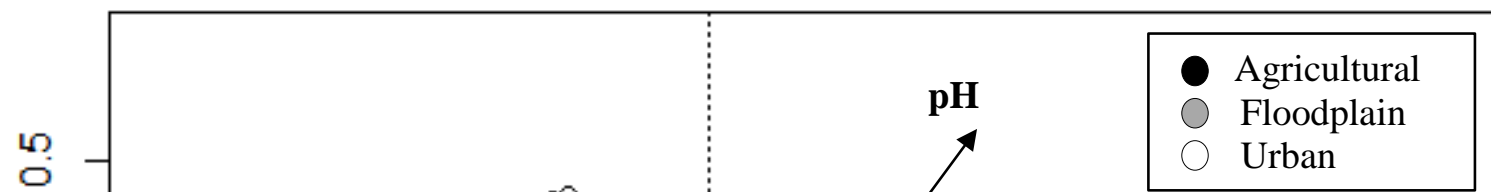

Emergent Macrophytes

Pond Margin
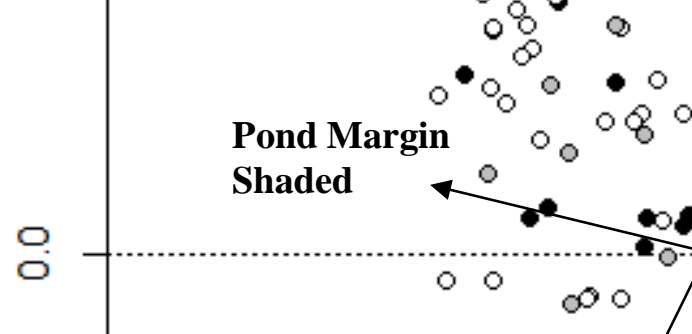

$0_{0}^{\circ}$
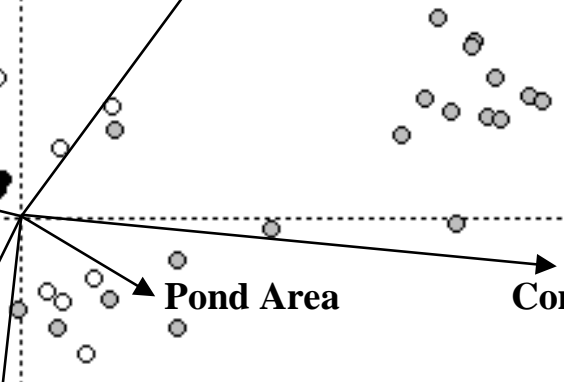

Pond Area

Connectivity
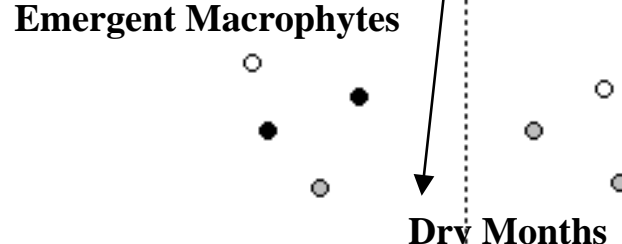

$\circ$

$\circ$

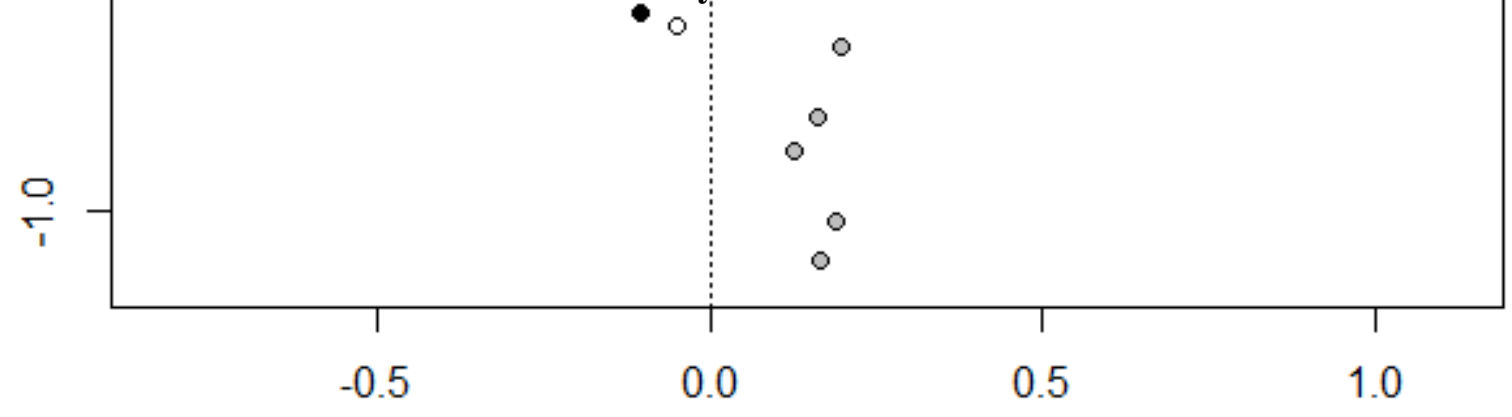

750

RDA1

751

752 Figure 5 - RDA ordination of site plots for floodplain, agricultural and urban pond macroinvertebrate

753 communities. Only significant environmental parameters are presented.

754

755

756

757

758 
760

761

762

763

764

765

766

767

768

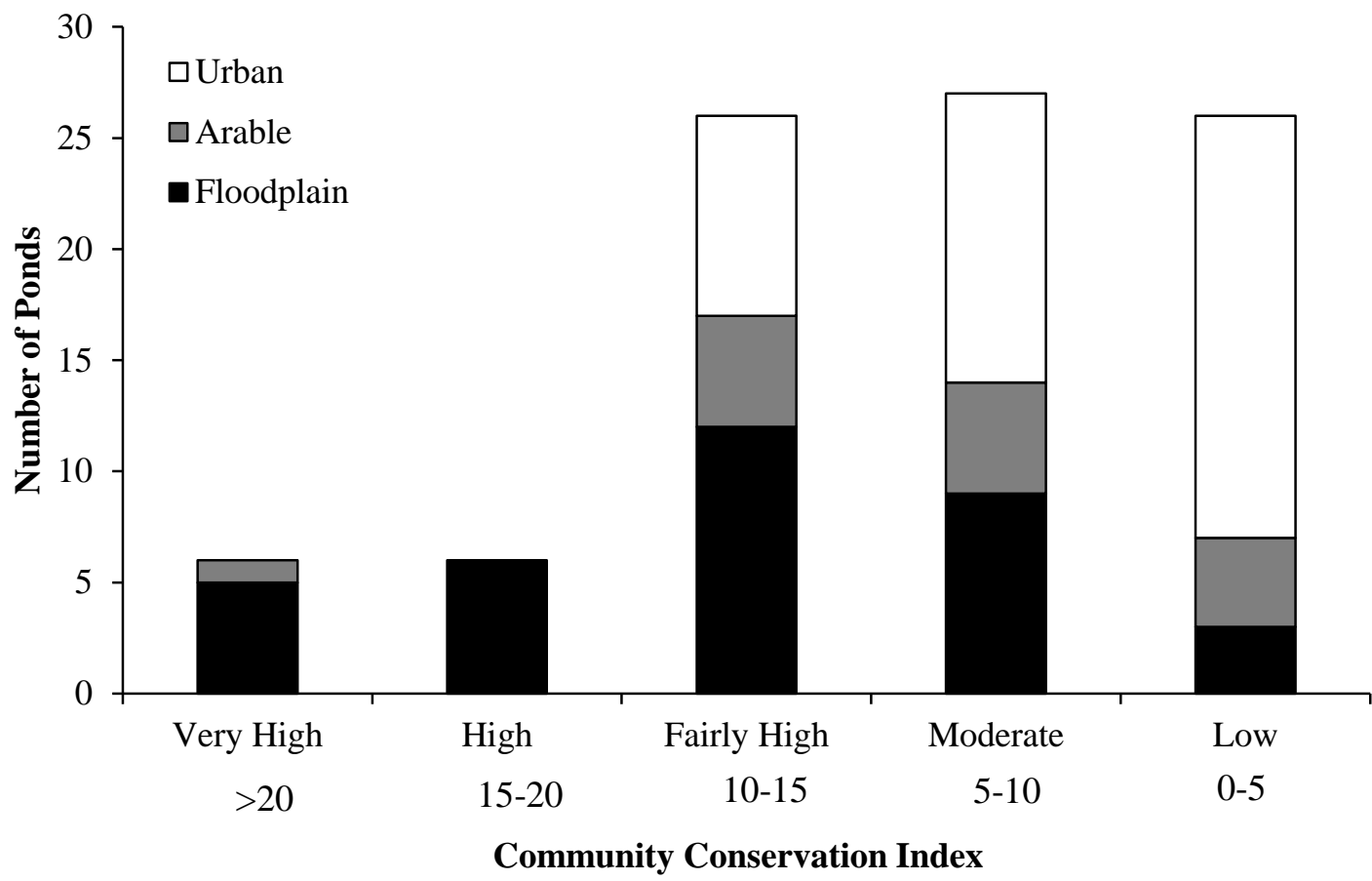

769

770 Figure 6 - The number of ponds determined as very high, high, fairly high, moderate and low

771 conservation value based on the Community Conservation Index (Chadd and Extence, 2004).

772 